\title{
SOBRE EL DERECHO A LA PROTESTA
}

Gustavo Alberto Manzo Ugas

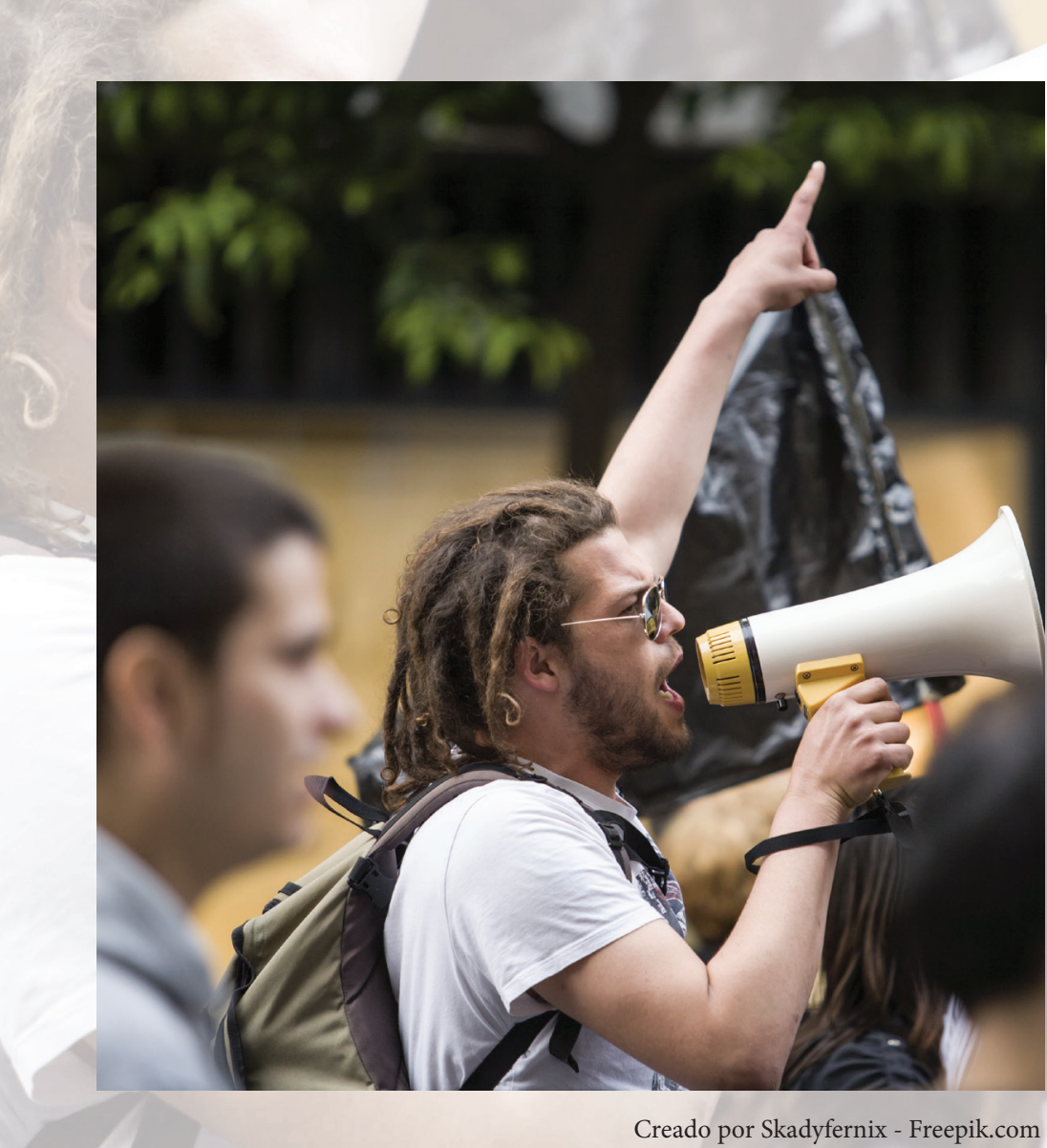





\title{
SOBRE EL DERECHO A LA PROTESTA
}

\author{
Gustavo Alberto Manzo Ugas \\ Universidad Central de Venezuela
}

\section{Resumen}

Esta investigación busca establecer las bases que definen el derecho a la protesta en varios países de América Latina. Se lleva a cabo un recorrido conceptual y teórico de los elementos que caracterizan este derecho humano y sus orígenes, para revisar diferentes sentencias de Tribunales Constitucionales que fijan su marco, en atención a los límites y las formas prescritas en estas y su vinculación con los postulados teóricos de los derechos humanos. Esto posibilita formarse una idea del estado actual de tan importante derecho, sus avances, retrocesos y expectativas. Asimismo, crea los fundamentos de los aportes que pueden hacerse para enriquecer las conductas y los derechos de los seres humanos.

Palabras clave: derecho a la protesta, sentencias, límites, derechos humanos, libertades.

El autor: profesor asistente de Derecho Constitucional de la Universidad Central de Venezuela. Correo electrónico: manzo.gustavo@gmail.com

Recibido: 24 de agosto de 2017; evaluado: 27 de septiembre de 2017; aceptado: 20 de noviembre de 2017. 


\title{
ON THE RIGHT TO PROTEST
}

\author{
Gustavo Alberto Manzo Ugas \\ Universidad Central de Venezuela
}

\begin{abstract}
This research seeks to establish the fundamental bases that define the Right to Protest in different countries of Latin America. In this line of thinking, a theoretical conceptual review is made of the elements that characterize this human right, its origins to review different Constitutional Courts that establish its framework, taking into account the limits and forms prescribed in them, and their overall link to the theoretical postulates of human rights, making it possible to picture the current status of such an important right, its advances, setbacks, and expectations. It also creates the fundamental bases of the contributions of this study to enrich the behaviors and rights of human beings.
\end{abstract}

Keywords: Right to protest, sentences, limits, human rights, freedom.

About the author: Assistant Professor of Constitutional Law from Universidad Central de Venezuela. E-mail: Correo electrónico: manzo.gustavo@gmail.com

Received: August 24, 2017; evaluated: September 27, 2017; accepted: November 20, 2017 


\section{Introducción}

Durante los últimos años, en América Latina se han presentado cambios en las condiciones sociales y políticas, los cuales han propiciado movimientos de diversa índole y han producido variedad de planteamientos para toda la sociedad. Algunas de estas corrientes han apuntado a múltiples aspectos que afectan al individuo o a la sociedad; muchos de los planteamientos que subyacen a ellas tienen contenidos que han estremecido las bases de la política y del derecho, no por lo novedosos, sino por la necesidad imperativa de rescatar al individuo y su esencia fundamental materializada en su libertad.

El individuo y su libertad han sido objeto de numerosas restricciones, cuya tendencia se nota en un incremento de las limitaciones a su espacio de actuación en los últimos cincuenta años. La restricción de los derechos que se toma en cuenta aquí es la relacionada con el derecho a la protesta y cómo esta ha sido tratada desde el Estado. Cuanto más se restringe el derecho de libertad de los ciudadanos, más se hará presente la protesta como elemento que busca oponerse a esa restricción $y$, por otro lado, mientras los derechos sociales no se hagan efectivos y se consiga un equilibrio que reduzca las iniquidades sociales, allí también se hará presente la protesta y la contestación.

Uno de los temas más importantes al cual se debe hacer referencia es la democracia. Protestar surge como una necesidad frente a la idea del Estado moderno, entendido como un ente que está por encima de los individuos por la suma de sus voluntades; una de las justificaciones más importantes de tal idea es la necesidad de establecer orden entre el grupo de individuos que ocupa un territorio determinado, en una condición social en la cual hay una eventual carencia de normas (anomia) o de orden, producto de la situación existencial de la sociedad y de lo natural que a cada individuo le corresponde afrontar. Dicho de otra forma, ontológicamente, el Estado no presenta el orden como característica, sino el desorden y el individuo protesta por las consecuencias del desorden.

La noción primigenia de Estado se basa en la necesidad de imponer el orden, producto de la legitimidad otorgada por la sociedad. Este orden deviene de lo normativo, que cobra fuerza mediante la legitimidad del voto y la decisión de la sociedad, en tanto el cuerpo social le dota de la facultad de imponer las decisiones que afectarán al propio individuo. Esto no es más que el viejo concepto de soberanía que se estudia en el derecho constitucional de los primeros años de la carrera. 
Se impone la decisión de la autoridad a todos sus ciudadanos aun en contra de la voluntad del sujeto obligado.

La protesta, como derecho constitucional, se origina en el disenso ante las decisiones del ente que está por encima de los individuos y la forma como este acepta y maneja el desacuerdo: si lo regula y limita o, por el contrario, lo permite. La tendencia dominante es a regular, por diferentes causas, la protesta y todo lo que ella signifique, pero, ante todo, limitar.

Podríamos pensar en un método tradicional para restringirla, que es convencer al pueblo de las bondades de determinada política o de una decisión específica mediante herramientas menos ortodoxas, pero más sutiles, que brindan la psicología social o la ciencia política, para manipular la voluntad de las masas y conseguir los objetivos propuestos. Así, por ejemplo, vemos la aplicación del populismo, una especie de extorsión sutil en la cual el pueblo recibe algo a cambio de su anuencia a determinada decisión.

La idea de Estado está condicionada a esta necesidad de orden, pero cuando este decide sobre materias o toma decisiones con las cuales una parte de la sociedad no está de acuerdo, la concepción que da origen al Estado puede convertirse en el mayor obstáculo para el grupo social que no concuerda con lo decidido.

El enfoque de este estudio no es sobre la decisión en sí misma, ya que se encaminaría al aspecto material de la democracia; tampoco tiene que ver con la forma en la que el Estado, el Gobierno o una parte más o menos importante de la sociedad toma sus decisiones, pues aludiría al elemento formal de la democracia. Atañe, sí, a la manera como la sociedad manifiesta su desacuerdo — sea cual sea su tamaño-y si esta expresión tiene un punto de llegada o si fenece en la voluntad en contra de la decisión. Entonces, surge la pregunta: ¿el desacuerdo o el disenso debe formar parte de la decisión del ente del Estado? En otras palabras, ¿hasta qué punto la activación de los derechos a la protesta, a la manifestación pacífica y a la resistencia u objeción de conciencia pueden constituir algo más que la mera protesta, materializarse en una parte de la obligación de escuchar y de tomar en cuenta por parte del ente decisor?

¿Qué derechos y qué previsiones poseen la democracia moderna y el Estado constitucional para que quien disienta de las decisiones del Estado o del Gobierno sea escuchado y tomado en cuenta? 
¿Cómo se expresa el desacuerdo con las decisiones tomadas: mediante protesta, manifestación, resistencia u objeción de conciencia? ¿De qué manera estas expresiones tienen efectos concretos en la esfera de lo tangible?

Las posiciones doctrinales han girado en torno a diferentes tópicos. Algunos autores se han centrado en llevar a cabo un análisis diferenciando del origen de los desacuerdos que ocasionan la protesta: si surge por los derechos sociales (vivienda, seguridad social, educación, salud, alimentación), la postura ante la protesta es diferente a si se tratara de derechos individuales (libertades personales). ${ }^{1}$

Las sociedades que consagran constitucionalmente el Estado social de derecho acentúan la importancia de lo colectivo y los Estados que consagran un modelo más cercano al liberal burgués modifican este acento y lo dirigen al individuo.

Otro de los argumentos que evidencia el análisis surge del concepto de democracia y su relación con el derecho de protesta. Temas como el Estado social de derecho, Estado liberal burgués y el concepto de democracia y otros como democracia representativa, democracia participativa, mayoría-minorías han sido objeto de interminables análisis y hoy siguen siendo estudiados e investigados y constituyen en sí mismos grandes puntos de discusión sobre lo preferible y viable de unos u otros para dar soluciones a las protestas surgidas en la sociedad.

En cuanto a la asunción del modelo de Estado social de derecho y la consecuencia de acentuar la importancia de lo colectivo sobre lo individual y su vínculo con el derecho de protesta se han producido diversas opiniones. Por ejemplo, Roberto Gargarella ha dicho:

Adviértase que lo que ocurre cuando se dice que los derechos sociales son "programáticos" es, en definitiva, que el juez pone en el cajón dicho derecho, esperando a que algún día el legislador se acuerde del mismo porque él ha decidido no hacer absolutamente nada al respecto. Los derechos sociales fueron incorporados en nuestra Constitución en 1957, es decir, no nacieron ayer, por más que se quiera postergarlos a un segundo lugar. ¿Se pretende entonces que alguien que tiene necesidades básicas insatisfechas no se queje? La Constitución le dice que tiene derecho a la compensación económica familiar y al acceso a una vivienda digna, y el juez le dice que no puede hacer nada al

\footnotetext{
Esta distinción entre derechos sociales y derechos individuales es pedagógica, pues desde el punto de vista de la teoría ambos son derechos humanos.
} 
respecto porque, por arte de magia, dichos aspectos de la Constitución han pasado a formar parte de la sección "no operativa" de la misma. En realidad estos casos deberían ser de fácil decisión, pero la realidad parece decirnos lo contrario. Lo que ocurre es que, en los hechos, los jueces tienen la capacidad de manipular nuestra Constitución a su gusto, haciendo un uso más bien discrecional de sus poderes interpretativos. ${ }^{2}$

En un estudio sobre el derecho a la protesta realizado por Personería de Medellín se hacen las siguientes afirmaciones en relación con el derecho a la protesta en Colombia:

En perspectiva a lo anterior, es recurrente cuando ocurren protestas encontrar visiones entre gobernantes, policiales y ciudadanía que enarbolan la primacía del derecho colectivo al individual y esgrimen que si un número determinado de personas está protestando, no puede impedir el derecho a la movilidad, el trabajo, la salud y otra serie de derechos que podrían ser obstaculizados por la realización en algún momento de un bloqueo en la vía, y estimulan en perspectiva de esto, que se castiga a los promotores de las protestas por las afectaciones a los derechos de otros y otras. Esta visión, que transfiere el conflicto hacia los ciudadanos y pierde de vista que si una protesta que reivindique derechos como la salud, la educación, el trabajo, la vida, si bien la puedan ejercer un número inferior de personas a los que inmediatamente pueden ser afectados, las demandas y potenciales beneficiarios, son esas mismas personas, más otras tantas, con lo que la primacía del derecho colectivo sobre el individual no aplica a favor de quien el derecho se le ve temporalmente interrumpido, sino de quienes ejercen el derecho a la protesta, en representación de las mayorías. Con lo anterior se tiene que aunque hay límites al derecho a la protesta, los límites deben entender el estado de necesidad de quien lo ejerce y releer la significación de derechos colectivos versus individuales a la hora de dirimir el conflicto de intereses. ${ }^{3}$

De igual forma ocurre entre los diversos conceptos de democracia y su nexo con el derecho a la protesta, sobre todo cuando se refiere a la democracia representativa y participativa. Carlos Pereda analiza el derecho a la protesta en la Constitución argentina y aduce:

Roberto Gargarella, "El derecho a la protesta social", Derecho y Humanidades, núm. 12 (2006): 141.

Personería de Medellín, "Protesta social: entre derecho y delito", Pensamiento Polítiko 2, núm. 2 (2010): 136.

http://dialnet.unirioja.es/descarga/articulo/3860600.pdf (acceso octubre 10, 2016). 
Entonces, para pensar qué ocurre con la ciudadanía en la práctica, siempre en relación a la temática analizada en el presente trabajo, haremos énfasis particularmente en dos artículos de la mencionada Constitución Nacional; porque en base a ellos girarán los argumentos, a favor y en contra, de la criminalización de la protesta. Nos referimos a los artículos 14 -1- (y 14 Bis -2-) y 22 -3-. El primero se refiere a los derechos económicos, políticos y sociales, los cuales a más de 50 años de su proclamación, aún están en discusión. Los debates son fruto tanto de su falta de efectivización como de la defensa de los mismos asumida por diversas organizaciones políticas y sociales. El segundo se ocupa del carácter representativo de la ciudadanía. Así, el Art. 22 delimita la participación del pueblo en las acciones de sus gobernantes, al señalar que la "ciudadanía práctica" se ejercería cada cuatro años a través del voto; aunque la Constitución plantee diferentes herramientas de participación ciudadana que también podrían utilizarse (como por ejemplo la consulta popular -4- ). Ambos artículos son parte de los distintos argumentos cuando de defender la protesta o de criminalizarla se trate. Y expresan que, en definitiva, lo que patrocinan unos y otros se refiere a diferentes formas de ejercicio de la ciudadanía: participativa, por un lado, y representativa, por otro.

Así, quienes propugnan la participación activa de los ciudadanos en ejercicio de sus derechos, y aun como contralor de las acciones estatales frente a incumplimientos del Art. 14; consecuentemente actúan y participan de su defensa exigiendo al Estado que los garantice. Los que abogan por la representación, hacen hincapié en la necesidad de "dejar gobernar" a las autoridades, de confiar en los representantes, de cuidar las instituciones y los funcionarios elegidos democráticamente, siendo dichas instituciones, en sus diversas instancias, los canales exclusivos de resolución de problemáticas. Ambos artículos, como veremos, se van resignificando y reinterpretando según la lupa de quien lo mire. ${ }^{4}$

Debe notarse también que al definir la participación como uno de los atributos de la democracia, las manifestaciones y protestas toman un lugar importante, pues serían formas en las cuales se materializa tal atributo de la democracia. Así se explica de la opinión de Carlos Pereda publicada en las investigaciones producidas por el Colectivo Ioé:

\footnotetext{
Colectivo Ioé, "La participación política de los españoles: democracia de baja intensidad", Papeles, núm. 99 (2007): 150. https://www.colectivoioe.org/uploads/1f938f585c6417albf7aal6aef90acdd262cf860.pdf
} 
Se entiende por participación directa en los asuntos públicos cualquier actividad, intervención o relación que los ciudadanos mantienen con las instancias e instituciones que están más allá de la esfera de la reciprocidad inmediata (parientes y amigos) y del intercambio mercantil (empleo y consumo). Tales relaciones y formas de intervención directa en la vida pública presuponen la voluntad de participar por parte de los ciudadanos, lo que depende a su vez de cuáles sean sus actitudes y opiniones respecto a las instituciones más amplias de las que forman parte. La participación directa en los asuntos públicos se puede ejercer esporádicamente, por ejemplo acudiendo a una manifestación, o de manera continuada, por ejemplo militando en un partido político. En ambos casos las formas concretas de participación presentan una gran diversidad y complejidad, lo que explica que la información disponible sobre estos asuntos sea heterogénea y difícil de captar con precisión y fiabilidad. ${ }^{5}$

En este trabajo, algunas de estas interrogantes serán tomadas en cuenta y otras no, para contribuir a la clarificación del sentido y alcance que el derecho a la protesta toma en la actualidad; por supuesto, no dejaremos de lado ni el derecho de resistencia ni la objeción de conciencia, pues se consideran expresiones importantes del disenso y, por ello, parte de la investigación.

En orden a las ideas expuestas, también se destaca en este estudio que el punto predominante del derecho a la protesta en todas las legislaciones de América Latina es la de ser un derecho constitucional limitado de diferentes formas, con lo cual se concluye lo expuesto en la introducción: el Estado regula la disidencia ante sus decisiones mediante diversos argumentos. Algunos de estos argumentos se basan en el derecho constitucional y propician diversas decisiones sobre las formas y el fondo del ejercicio del derecho a la protesta. Otras, en cambio, utilizan la vía del derecho penal para establecer punibilidad sobre la conducta que materializa la protesta y que se ha denominado de manera coloquial "criminalización de la protesta".

\section{Derecho a la protesta, desobediencia civil y objeción de conciencia}

Las vinculaciones entre el derecho a la protesta, la desobediencia civil y la objeción de conciencia son múltiples y varios doctrinarios se han referido al tema.

Colectivo Ioé, "La participación política de los españoles: democracia de baja intensidad", 150. 
El origen común de estos tres derechos se halla en decisiones del Estado y del Gobierno que lleva las riendas, las cuales afectan la esfera de las libertades o los derechos humanos de una parte de la población. Por ejemplo, podríamos pensar en decisiones que afecten a una importante porción de la sociedad y que prohíba escoger determinada carrera de estudios; otro ejemplo podría ser el establecimiento de nuevos y amplios requisitos para dedicarse a ciertas actividades o la imposición de controles de precios a algunos rubros que, a su vez, ocasionan desabastecimiento e inclusive unas aún más polémicas, como la penalización del aborto. Estas decisiones en sí mismas podrían tener que ver con lo más íntimo de cada persona y generar argumentos y posturas en contra de ellas. La historia está llena de estos hechos.

El título de este aparte va orientado a estudiar la conducta que desarrollan los seres humanos cuando las decisiones que toma el Gobierno tocan nuestro sistema de creencias y provocan la protesta, la desobediencia o la objeción de conciencia.

Si aventuramos unas definiciones, podríamos afirmar que la protesta es un acto, una actividad (también puede ser una omisión o falta de actividad), una conducta del individuo que está en contra de una decisión tomada por el Estado o, de manera más amplia, por el statu quo.

Para definir la objeción de conciencia nos valdremos de esta opinión del Grupo Interdisciplinario de Bioética, que nos dice:

La objeción de conciencia consiste en la oposición, claramente manifestada, de una persona a un imperativo legal o a una autoridad, basada en los propios principios morales. Por eso, se acostumbra a definir la objeción de conciencia en términos que subrayan el rechazo, por coherencia con los principios de la propia conciencia, a una orden particular, al ordenamiento jurídico o a una práctica determinada que obliga a la persona, sea individualmente, profesionalmente o corporativamente. Aun cuando la mayoría de los posicionamientos actuales sobre la objeción de conciencia la limitan o restringen a la negativa al cumplimiento de un deber legal, entendemos que el derecho moral a la objeción de conciencia puede manifestarse también como oposición al cumplimiento de un deber o responsabilidad no explicitada en ninguna norma legal, pero sí deontológica o profesional. En este sentido, es un derecho moral diferente y previo a su reconocimiento jurídico, tal y como lo denota el hecho de que la auténtica objeción, históricamente practicada, es la que no admite ni prevé 
la ley y el objetor la ejerce hasta sus últimas consecuencias, aceptando el castigo que se pueda derivar, en defensa de sus propios valores. ${ }^{6}$

La protesta es la más común de todas las formas de disenso y a ella seguiremos haciendo referencia.

Por otro lado, de acuerdo con la doctrina, la desobediencia toca aspectos de la ciencia política, del poder, de la forma como se dirime la tenencia y del ejercicio del poder en la sociedad. En cambio, la objeción de conciencia, según algunos científicos del derecho, se enfoca en aspectos de naturaleza moral; no obstante esta afirmación, Prieto Sanchíz analiza una decisión del Tribunal Constitucional español y aduce lo siguiente:

[...] concibe la libertad de conciencia — nomen iuris, que no aparece en la Constitución - como una síntesis de los tres derechos mencionados en el art. 16,1, atribuyéndole un contenido amplísimo que consiste no sólo en creer o dejar de creer lo que se tenga por conveniente, sino sobre todo en comportarse en la vida personal y social de acuerdo con las propias convicciones, en principio cualesquiera que éstas sean. Y, por último, afirma que la objeción de conciencia en un derecho fundamental reconocido por partida doble, explícitamente en el art. 30,2 en su versión de objeción al servicio militar, e implícitamente en el art. 16,1, lo que estimula una interpretación más que generosa de la objeción en particular y de los derechos fundamentales en general, como veremos enseguida [...]. ${ }^{7}$

En relación con los aspectos de fondo, el primer pronunciamiento decisivo es este: "[... la libertad de conciencia supone no solamente el derecho a formar libremente la propia conciencia, sino también a obrar de manera conforme a los imperativos de la misma". ${ }^{8}$ Parece una verdad bastante obvia que la libertad de conciencia no puede referirse jurídicamente a una facultad interna o psicológica, esfera en la que el derecho y el poder aún se muestran incompetentes (cogitationis poenam nemo patitur), sino a una capacidad práctica y social, que protege al individuo frente a

6 Grupo interdisciplinario de Bioética, "Objeción de conciencia en el ámbito de los profesionales de la salud", Bioética y Debate 18, núm. 66 (2012) http://www.bioetica-debat.org/contenidos/PDF/BD66ESP.pdf (acceso octubre 10, 2016).

7 Luis Prieto Sanchís, "Libertad y objeción de conciencia". Persona y Derecho 54 (2006): 259. http://hdl. handle.net/10171/14621 (acceso octubre 10, 2016).

8 Prieto Sanchís, "Libertad y objeción de conciencia", 259. 
las coacciones o interferencias que pudiera sufrir por comportarse de acuerdo con sus creencias o convicciones.

Pensamos que cuando Prieto Sanchíz menciona el alcance amplio de este derecho y se refiere a diferentes ámbitos (religioso, económico, servicio militar, reclutamiento para ir a la guerra) ha causado polémica en varios países.

Parte de la población convertida en sujeto pasivo de las decisiones tomadas por el Estado, representado en el órgano gubernamental, puede estar configurada de cualquier modo y ser mayoría o minoría; lo importante es que sus derechos están afectados de una u otra forma y que tal afectación produce un rechazo que se expresa mediante la protesta, la desobediencia o la objeción de conciencia. La opinión de Matías Esteban Ilivitzky, quien cita a Norberto Bobbio, es pertinente:

Además de esta última alternativa, existe en la época contemporánea otra forma de manifestar rechazo al orden constituido: la contestación. Mientras que el desobedecer es un acto de protesta que busca poner en crisis el conjunto del sistema sociopolítico y que puede eventualmente recurrir al uso de la violencia, la última alternativa es sencillamente la no aceptación de las reglas vigentes y la emisión, por consiguiente, de un discurso crítico que ataca, tanto al subsistema político, como al modelo cultural general en el que esa comunidad dada se encuentra inmersa. En este sentido, su violencia es meramente ideológica y su accionar nulo. Su ámbito de desenvolvimiento puede ser, por ejemplo, una asamblea (Bobbio, 1991: 480-481; 2005: 277). ${ }^{9}$

En la misma obra, Ilivitzky incorpora una opinión de Arendt que guarda la misma pertinencia referida:

Los movimientos universitarios de protesta, así como las manifestaciones públicas en contra de la guerra de Vietnam y de la corrupción de la administración Nixon en el caso Watergate, le servirán de marco a Arendt para sostener que una criminalización de esa forma particular de disenso significaría la persecución de una de las libertades básicas garantizadas por la primera enmienda constitucional estadounidense, referida a la posibilidad de peticionar y de cuestionar a las autoridades públicas. ${ }^{10}$

\footnotetext{
9 Matías Esteban Ilivitzky, "La desobediencia civil: aportes desde Bobbio, Habermas y Arendt", CONfines 7, núm. 13 (2011), http://confines.mty.itesm.mx/articulos13/IlivitzkyM.pdf (acceso octubre 10, 2016).

10 Ilivitzky, "La desobediencia civil", 17.
} 
El derecho a oponerse a una decisión contra los principios de cualquier persona, por ejemplo, está en el derecho natural y nunca puede ser considerado una forma de anarquía o rebelión. Si la autoridad interactúa de una forma más horizontal, la relación individuo-sociedad será más eficaz.

Henry David Thoreau se hace el siguiente cuestionamiento acerca de qué surge primero, si el ciudadano o el ser humano: ¿Cuál condición debe ser primero atendida? Su respuesta es que la primera responsabilidad es del ser humano consigo mismo y el ejercicio del Gobierno es una excusa, pues su conformación es de seres humanos cuya responsabilidad primigenia no es con ellos mismos. ${ }^{11}$ La ley es una expresión incompleta y esencialmente sujeta a ser violada si representan una transgresión a las propias creencias. La responsabilidad de un cambio masivo o de generar una revolución no radica en un solo individuo; cada uno debe ser consecuente con su conciencia para llegar a una sociedad justa.

Thoreau nos dice lo siguiente:

Hay leyes injustas: ¿nos contentaremos con obedecerlas o intentaremos corregirlas y las obedeceremos hasta conseguirlo? ¿O las transgrediremos desde ahora mismo? Bajo un gobierno como este nuestro, muchos creen que deben esperar hasta convencer a la mayoría de la necesidad de alterarlo. Creen que si opusieran resistencia el remedio sería peor que la enfermedad. Pero eso es culpa del propio gobierno. ¿Por qué no está atento para prever y procurar reformas? ¿Por qué no aprecia el valor de esa minoría prudente? ¿Por qué grita y se resiste antes de ser herido? ¿Por qué no anima a sus ciudadanos a estar alertas y a señalar los errores para mejorar en su acción? ¿Por qué tenemos siempre que crucificar a Cristo y excomulgar a Copérnico y Lutero y declarar rebeldes a Washington y Franklin?

Se pensaría que una negación deliberada y práctica de su autoridad es la única ofensa que el gobierno no contempla; sino, ipor qué ha señalado el castigo definitivo, adecuado y proporcionado? Si un hombre sin recursos se niega una sola vez a pagar nueve monedas al Estado, se le encarcela (sin que ninguna ley de que yo tenga noticia lo limite) por un periodo indeterminado que se fija según el arbitrio de quienes lo metieron allí; pero si hubiera robado noventa veces nueve monedas al Estado, enseguida se le dejaría en libertad.

11 Henry D. Thoreau, Desobediencia civil y otros escritos (Madrid: Tecnos, 2008), 33. 
Si la injusticia forma parte de la necesaria fricción de la máquina del gobierno, dejadla así, dejadla. Quizás desaparezca con el tiempo; lo que sí es cierto es que la máquina acabará por romperse. Si la injusticia tiene un muelle o una polea o una cuerda o una manivela exclusivamente para ella, entonces tal vez debáis considerar si el remedio no será peor que la enfermedad; pero si es de tal naturaleza que os obliga a ser agentes de la injusticia, entonces os digo quebrantad la ley. ${ }^{12}$

En la misma línea de pensamiento, es posible relacionar estos conceptos esgrimidos por Thoreau con temas expuestos en la novela de George Orwell, 1984, en la que "el Gran hermano" tenía como objetivo lograr que, mediante el uso del poder del Estado, los ciudadanos de Oceanía pensaran de manera uniforme al sistema imperante, al statu quo. Evidentemente, al uniformar el pensamiento de la sociedad no encontraremos ni desobediencia, protesta ni objeción de conciencia.

En una mirada más amplia podríamos recoger estas tres formas de conductas en una sola: la disensión, la cual es definida por Bobbio de la siguiente manera:

Una definición precisa y unívoca de disensión es difícil de formular, sobre todo por dos motivos. En primer lugar, con el término disensión son denotados a menudo fenómenos bastante diferentes. La disensión adquiere así un significado muy amplio y con contornos indefinidos. Un segundo motivo, que en parte se superpone al primero, es que no menos a menudo se provoca confusión entre los términos que indican diversos tipos de comportamiento negativos hacia el sistema político. Más exactamente es la confusión entre disensión, desobediencia civil u oposición o también violencia. Una prueba ulterior de esta afirmación reside en el hecho de que se trata de disensión sobre todo en escritos sobre la desobediencia civil, sobre la oposición o sobre la protesta, violenta o no violenta.

En realidad los motivos que explican las dificultades de definición tienen un fundamento serio si considera, como se propone aquí, que la disensión —o sea, el contrario de consenso- es la categoría más general y comprehensiva de toda forma de desacuerdo y de actitud negativa hacia el sistema político o sus aspectos más específicos. Desde este punto de vista, la desobediencia civil,

12 Thoreau, Desobediencia civil y otros escritos, 40. 
las diversas formas de oposición y de protesta son manifestaciones típicas y muy particulares de disensión. ${ }^{13}$

En cuanto a la objeción de conciencia, no podemos dejar de mencionar los casos que son un faro para la lucha por lo que cada ser humano cree, piensa y siente y cómo debe ser tomado en cuenta. El primero es el suicidio de Sócrates, quien luego de una sentencia injusta bebió cicuta, para incumplir la decisión; igual ocurrió con Antígona, de Sófocles, quien desobedeció al rey Creonte, alegando que la ley era superior a la decisión real.

Por supuesto, no se pueden pasar por alto las persecuciones religiosas, por las cuales la negativa a aceptar la religión del Imperio trajo la muerte por crucifixión y se ordenaba a los cristianos a participar en la guerra en contra de su voluntad.

En esa gran lista de personas que llevaron a la máxima expresión su objeción de conciencia está Tomás Moro que, por oponerse al rey Enrique VIII, fue decapitado. El famoso boxeador Cassius Clay fue encarcelado por negarse a pelear en la guerra; por ello y por su condición religiosa cambió su nombre por Mohamed Ali. Otro caso famoso es el del soldado Desmond Doss, que fue inmortalizado en la película Hasta el último hombre.

Una última definición de objeción de conciencia, de Carlos Simón Vázquez, se agrega a este estudio, pues comprende elementos de importancia a ser considerados:

La oc es la negativa de un individuo a cumplir lo mandado por una norma concreta del ordenamiento jurídico por entender que su cumplimiento es incompatible con el respeto a un determinado valor moral percibido por la propia conciencia. En su propia noción atestigua la existencia de un conflicto entre una doble obediencia: la obediencia a la ley y la obediencia al juicio de la conciencia. Tiene la apariencia de un conflicto de deberes. Deberes reconocidos por la persona como vinculantes en relación a la legislación y al juicio de conciencia. Sólo en este contexto se enmarca la objeción de conciencia. En absoluto se trata de un intento de desprecio a la legalidad o al intento de desobediencia arbitraria frente a la norma positiva. Tampoco en la oc se apela a una autonomía monádica de la conciencia en el sentido de ser la conciencia

13 Norberto Bobbio, Nicola Metteucci y Gianfranco Pasquino, Diccionario de política (Ciudad de México: Siglo XXI Editores 2007), 507. 
exclusivamente ley para uno mismo, como si ésta, la conciencia, no debiera seguir a la ley en la consecución del propio bien personal. No se funda ni en la pretendida autonomía del sujeto respecto a la norma ni al desprecio de la ley civil, sino a la fidelidad a la misma fundamentación de la ley civil como arriba hemos apuntado en el obligado servicio al bien moral. ${ }^{14}$

De vuelta al tema de la protesta, veamos la opinión de Roberto Gargarella en relación con los conceptos referidos en esta investigación:

La discusión de todos modos, tiende a ponerse más interesante cuando los jueces y juristas abandonan la idea de que hay que limitar los derechos en nombre del bien común o de la eficiencia económica y pasan a sostener que, en verdad, lo que ellos proponen es limitar los derechos de los manifestantes, pero (y aquí aparece la diferencia con los casos anteriores) sólo en nombre de los derechos de los demás individuos. Nos dicen entonces: Lo que pasa es que acá se enfrenta un derecho con otro derecho. Es cierto, entonces, que proponemos limitar ciertos derechos, pero lo que ocurre en este caso es que el derecho de los manifestantes choca, en este caso, con los derechos de los demás. La pregunta "dónde terminan mis derechos" no obtiene respuesta en la perogrullada "donde comienzan los de los demás". ${ }^{15}$

Estas afirmaciones precedentes no colaboran en la solución de las discusiones que se presentan en el ámbito público y tampoco en el campo del derecho administrativo o de los tribunales en sede jurisdiccional; los planteamientos son conflictivos y quedan en lo elemental del argumento. Esta característica de elemental trae como consecuencia la frustración del ser humano, sobre todo cuando el poder en manos de su representante no se convierte en caja de resonancia de aquello que el ciudadano pretende.

Aunque no es el tema que nos ocupa, el derecho de resistencia posee un lugar junto a los derechos que encabezan este capítulo; sin embargo, no se aborda para mantener el hilo conductor, que es el derecho a la protesta.

14 Carlos Simón Vázquez, "La objeción de conciencia en la práctica médica" en Actas del I Congreso internacional multidisciplinar Mujer y realidad del aborto, ed. Lázaro Pulido (Cáceres: Asociación Extremeña de Amigos del Foro Español de la Familia, 2008), 194.

15 Roberto Gargarella, Carta abierta sobre la intolerancia. Apuntes sobre derecho y protesta (Ciudad de México: Siglo XXI Editores, 2006), 20. 
Invocar la resistencia como derecho implica que en el Estado y en la sociedad está presente una situación que lleva a pensar que no queda otro remedio que resistir. Se trata de un punto en el cual el Estado de derecho y el Estado constitucional son incapaces de dar respuestas y soluciones a los problemas que la sociedad plantea, lo que obliga a los individuos a asumir una actitud de contumacia o rebeldía. El derecho a la resistencia se origina en la crisis del derecho o, en otras palabras, el derecho que encarna la injusticia. El supuesto fáctico principal para invocar el derecho de resistencia es el derecho injusto y, por ello, este último es ubicable como institución jurídica en el derecho natural.

Mencionar el derecho de resistencia es imposible sin la referencia histórica a la Vindiciae contra tyrannos (defensa contra los tiranos), cuyo autor se halla en discusión hasta la fecha, pero su contenido marca los elementos principales de la defensa de la dignidad humana. Francisco Suárez menciona:

[...] Si el príncipe persiste y no rectifica [...] sino que tiende a cometer impunemente todo el mal que le plazca, entonces es en verdad culpable declarado de tiranía, y es lícito ejercer contra él cuanto el derecho o una justa violencia permita contra un tirano $[\ldots]^{16}$

La premisa inicial para el ejercicio del derecho a la resistencia es lo que Gargarella denomina "situaciones de alineación ilegal", ${ }^{17}$ es decir, el tema va más allá de los límites propios del derecho a la protesta, en la cual la situación fáctica no es la alienación, sino el desacuerdo con una o varias decisiones de quien detenta el poder. No obstante, se finaliza este pequeño ex cursus con lo que menciona el autor:

En tales situaciones, cuando el Estado comienza a utilizar su fuerza en favor del mantenimiento de una situación institucional fundamentalmente injusta, es que pueden aparecer o pueden resultar justificadas ciertas acciones de resistencia: el grado en que ello sea así dependerá, por supuesto, del mayor o menor nivel de "alienación legal" existente. ${ }^{18}$

16 Francisco Suárez, Guerra, intervención y paz internacional, trad. Luciano Pereña y Vicente (Madrid: EspasaCalpe, 1956), 10.

17 Roberto Gargarella, "La última carta. El derecho de resistencia en situaciones de alienación legal", SELA (Seminario en América Latina de teoría constitucional y política) Papers, núm. 24 (2003), http://digitalcommons. law.yale.edu/yls_sela/24/

18 Gargarella, "La última carta". 


\section{Análisis comparado de las decisiones que regulan la forma y el fondo del derecho a la protesta}

\section{Colombia}

La Corte Constitucional colombiana se refirió al derecho a la protesta y destacó varias características útiles para este estudio:

4.1. En Colombia el derecho a reunirse y manifestarse pública y pacíficamente está expresamente reconocido en la Constitución Política y por los tratados internacionales que hacen parte del bloque de constitucionalidad. El artículo 37 de la Constitución consagra este derecho, en los siguientes términos: "Toda parte del pueblo, puede reunirse y manifestarse pública y pacíficamente. Sólo la ley podrá establecer de manera expresa los casos en los cuales se podrá limitar el ejercicio de este derecho".

4.2. Esta norma, a diferencia del artículo 46 de la Constitución de 1886[42] que sólo consagraba el derecho de reunión,[43] incorpora el derecho de manifestación, garantizando en ambos casos su ejercicio público y pacífico, y estatuye que sólo la ley podrá señalar expresamente los casos en los cuales puede limitarse el ejercicio de este derecho. [44] El derecho a reunirse y manifestarse pública y pacíficamente, ha sido reconocido por esta Corporación como una de las varias manifestaciones que tiene la libertad de expresión[45] (artículo 20, $\mathrm{CP}$ ). Dentro de un régimen jurídico pluralista que privilegia la participación democrática y que además garantiza el ejercicio de otros derechos de rango constitucional como la libertad de locomoción (art. 24, CP) y los derechos de asociación (artículo 38, CP) y participación en los asuntos públicos (artículos 2 y 40,CP), la protesta social tiene como función democrática llamar la atención de las autoridades y de la opinión pública sobre una problemática específica y sobre las necesidades que ciertos sectores, en general minoritarios, para que sean tenidos en cuenta por las autoridades.

4.3 Por lo demás, la Constitución Política garantiza el derecho a reunirse y manifestarse públicamente tanto en una dimensión estática (reunión) como dinámica (movilización), de forma individual como colectiva, sin discriminación alguna. Así se deriva de la expresión "toda parte del pueblo", sin otra condición a que sea pacífico, o sea, sin violencia, armas ni alteraciones graves del orden público. Esto significa que solo la protesta pacífica goza de protección 
constitucional. Aun reconociendo la tensión que surge entre el ejercicio del derecho de reunión y manifestación pública y pacífica y el mantenimiento del orden público, el Legislador no puede desbordar los principios de razonabilidad y proporcionalidad al establecer restricciones cuya vaguedad conduzca a impedir tal derecho. ${ }^{19}$

Los siguientes aspectos de la cita que se revisó son relevantes:

- Se reconoce el derecho de manifestación pacífica.

- La ley puede establecer límites al derecho de manifestación pacífica.

- El derecho de manifestación pacífica es consecuencia del derecho de libertad de expresión.

- El objeto de la protesta es llamar la atención de autoridades y opinión pública sobre determinada situación.

- El derecho de manifestación pacífica tiene una dimensión estática (reunión) y dinámica (movilización).

- Límites: sin violencia, armas o alteraciones graves del orden público.

Cuando se contrastan estos criterios con los postulados expuestos en la introducción de este trabajo, el que más resalta por su coincidencia es el denominado objeto de la protesta, pues debe notarse que consiste en llamar la atención de autoridades y opinión públicas. Ante este límite surgen algunas interrogantes: ¿Qué ocurre si la situación que genera la protesta pacífica permanece inmutable? ¿Hay una obligación de las autoridades de escuchar o de resolver aquello que se plantea en la protesta?

En estas interrogantes subyace una situación que consideramos debe ser revisada. Por medio de sus canales, autoridades legítimamente constituidas o Gobierno, el Estado toma decisiones que gozan del poder de la coerción y, en muchas oportunidades, cuando se pretende que la autoridad rectifique, la modificación no se lleva a cabo.

19 Colombia, Corte Constitucional, Sentencia C-742 de 26 de septiembre de 2012, M. P. María Victoria Calle Correa. 
En otras palabras, la estructura del Estado está diseñada para que en muy pocos casos pueda ser obligada a escuchar o a rectificar. De allí la necesidad de una auténtica separación de poderes que garantice la autonomía e independencia del poder Judicial, ya que en el momento en el que una situación como la planteada llegue a manos de los tribunales, estos podrían obligar al Estado a una determinada actuación. Se trata de una garantía que resguarda la sociedad democrática de dos formas: a) protege el disenso de una parte de la sociedad, cualquiera que sea su tamaño (el disenso y la forma de canalizarlo es esencial en democracia), y b) al establecerse la necesidad de la autonomía del poder Judicial y de la separación de poderes, en el fondo se está garantizando la existencia de la democracia en la sociedad en la cual se presenta la protesta. En resumen, la protesta debe tener un punto de llegada y no debe ser considerada solo para llamar la atención de las autoridades; de esta forma, sería fútil y sin sentido, nada más que la expresión de una rabieta social.

El aspecto que se viene considerando abre otro tópico a considerar: la efectividad de los derechos humanos y cómo garantizarla; se hace la salvedad con respecto a la expresión "derechos humanos", pues en esta incluimos a los derechos individuales y los sociales. Para profundizar, es necesario afirmar que los derechos humanos enfocados en el individuo tienen una mayor efectividad, porque gozan de una tradición y una historia más desarrollada que los derechos humanos que se enfocan en el colectivo.

El origen de los derechos sociales se remonta a finales del siglo XIX y principios del siglo XX, mientras los individuales se ubican a partir del siglo XII. Sin embargo, durante las últimas cinco décadas, los ordenamientos jurídicos en el mundo vienen dando un giro con miras a garantizar mayor efectividad de los derechos sociales. De tal forma, la educación, el trabajo, la seguridad social, la vivienda y la protección de la familia como célula fundamental de la sociedad gozan de un avance en cuanto a su cumplimiento efectivo, pero falta mucho por recorrer para que pueda considerarse que están en el mismo punto que los derechos individuales.

Un aspecto importante que la sentencia no menciona es que no existe obligación alguna por parte del Estado para que dé respuesta a los planteamientos esgrimidos en la protesta, sea cual sea su causa y tampoco toca elementos como el grado de necesidad en el cual se halla el protestante. 


\section{Venezuela}

En Venezuela se emitió una sentencia que alude el derecho a la protesta, distinguida con el número 276 del 24 de abril de 2014 del Tribunal Supremo de Justicia en Sala Constitucional sobre el Artículo 68 de la Constitución de la República Bolivariana de Venezuela. Esta decisión es producto de un recurso interpuesto por el ciudadano Gerardo Sánchez Chacón, que actuó en su condición de alcalde del municipio de Guacara del estado Carabobo, asistido por el abogado Hermann Escarrá Malavé.

Cuando se solicita la interpretación de una norma constitucional se aplica el Artículo 335 de la Carta Magna, que fija el alcance de tal interpretación.

El planteamiento del derecho a la protesta o manifestación pacífica es similar en casi todas las Constituciones de América Latina; en la mayoría de países se han presentado controversias parecidas cuando la norma remite al desarrollo legal de los límites a este derecho humano.

En consecuencia, para comprender la sentencia que se pretende analizar, debemos partir del derecho y del tipo de derecho que ella contiene.

El Pacto internacional de derechos civiles y políticos del 16 de diciembre de 1966, vigente desde el 23 de marzo de 1976, estableció:

Se reconoce el derecho de reunión pacífica. El ejercicio de tal derecho sólo podrá estar sujeto a las restricciones previstas por la ley que sean necesarias en una sociedad democrática, en interés de la seguridad nacional, de la seguridad pública o del orden público, o para proteger la salud o la moral públicas o los derechos y libertades de los demás. ${ }^{20}$

Esto quiere decir que el derecho a la protesta pacífica tiene un contenido y lo primero que debe señalarse es que la Sentencia 276 de 24 de abril de 2014 del Tribunal Supremo de Justicia en Sala Constitucional no analiza ese contenido de manera profunda y pormenorizada. Se limita casi en exclusiva a la salvedad que establece el Artículo 68, es decir, analiza esta frase: "[...] sin otros requisitos que los que establezca la ley".

20 Organización de Naciones Unidad [ONU], Pacto internacional de derechos civiles y políticos (Nueva York, 16 de diciembre de 1966), art. 21. 
Lo expuesto por el Tribunal guarda congruencia con las sentencias que se presentan en el derecho comparado; no obstante, el alejamiento al tratamiento común que se otorga a la manera en la cual se regula este derecho viene en este planteamiento:

Pues nada escapa de manera más evidente a la constitucional configuración del derecho sub examine. En efecto, el derecho de reunión es de eficacia inmediata y directa, de manera tal que no requiere de ningún tipo de autorización previa para su ejercicio.

Lo que ocurre es que, en el caso específico de las reuniones convocadas en plazas o vías públicas, el constituyente ha establecido un instrumento expreso de armonización entre su ejercicio y las eventuales restricciones a otros derechos que éste represente, de manera tal que ordena que la autoridad tome noticia del evento con antelación suficiente a efectos de que tome las providencias necesarias para que el derecho al libre tránsito (artículo $2^{\circ} 11$ de la Constitución) no se vea limitado más allá de lo estrictamente necesario, habilitando vías alternas de circulación, además de adoptar las medidas necesarias para proteger a los manifestantes y asumir una conducta vigilante y, de ser el caso, proporcionalmente represiva, frente a las eventuales afectaciones a la integridad personal de terceros o de los bienes públicos o privados.

Así las cosas, no cabe confundir la exigencia de aviso previo, con un supuesto sometimiento del derecho de reunión a la necesidad de una autorización previa de la autoridad administrativa, la cual, de ser exigida, resultará manifiestamente inconstitucional [9]. ${ }^{21}$

Cabe señalar que, en el punto relativo a la autorización o notificación de la manifestación, la negativa de la autorización convierte la manifestación en ilícita y textualmente establece:

La autorización emanada de la primera autoridad civil de la jurisdicción de acuerdo a los términos de la Ley de Partidos Políticos, Reuniones Públicas y Manifestaciones, constituye un requisito de carácter legal, cuyo incumplimiento limita de forma absoluta el derecho a la manifestación pacífica, impidiendo así la realización de cualquier tipo de reunión o manifestación. Por lo tanto,

21 República Bolivariana de Venezuela, Tribunal Supremo de Justicia, Expediente $N^{o} 140277$ de marzo de 2014, M. P. Arcadio Delgado Rosales. 
cualquier concentración, manifestación o reunión pública que no cuente con el aval previo de la autorización por parte de la respectiva autoridad competente para ello, podrá dar lugar a que los cuerpos policiales y de seguridad en el control del orden público a los fines de asegurar el derecho al libre tránsito y otros derechos constitucionales (como por ejemplo, el derecho al acceso a un instituto de salud, derecho a la vida e integridad física), actúen dispersando dichas concentraciones con el uso de los mecanismos más adecuados para ello, en el marco de lo dispuesto en la Constitución y el orden jurídico.22

En el estudio de diferentes decisiones de los tribunales o salas constitucionales de América Latina y de las normas constitucionales relativas al derecho a la manifestación pacífica no se consiguen precedentes que exijan la autorización previa como requisito de licitud del derecho humano que se analiza.

Para resumir el contenido material del derecho a la manifestación pacífica enumeraremos sus elementos:

- El titular es un individuo, pero puede ejercerse de manera colectiva.

- Tiene naturaleza temporal, aun cuando puede presentarse periódicamente.

- Su finalidad debe ser lícita.

- Se ejerce en un espacio determinado.

- Debe ser avisado o notificado previamente, lo que no significa que debe ser expresamente autorizado.

Vale la pena revisar la opinión de la Relatoría especial para la libertad de expresión que traza la amplitud con la cual debe ser tratado el contenido material del derecho humano a la manifestación pacífica:

Naturalmente las huelgas, los cortes de ruta, el copamiento del espacio público e incluso los disturbios que se puedan presentar en las protestas sociales pueden generar molestias o incluso daños que es necesario prevenir y reparar. Sin embargo, los límites desproporcionados de la protesta, en particular cuando

22 República Bolivariana de Venezuela, Tribunal Supremo de Justicia, Expediente No 140277. 
se trata de grupos que no tienen otra forma de expresarse públicamente, comprometen seriamente el derecho a la libertad de expresión. Preocupa por ello a la Relatoría Especial la existencia de disposiciones penales que convierten en actos criminales la simple participación en una protesta, los cortes de ruta (a cualquier hora y de cualquier tipo) o los actos de desorden que en realidad, en sí mismos, no afectan bienes como la vida o la libertad de las personas. ${ }^{23}$

Por otra parte, el Artículo 15 de la Convención americana sobre derechos humanos expresa:

Se reconoce el derecho de reunión pacífica y sin armas. El ejercicio de tal derecho sólo puede estar sujeto a las restricciones previstas por la ley, que sean necesarias en una sociedad democrática, en interés de la seguridad nacional, de la seguridad o del orden públicos, o para proteger la salud o la moral públicas o los derechos o libertades de los demás.

Ningún aspecto del derecho humano de manifestación pacífica definido en el Artículo 68 de la Constitución venezolana, en cuanto a su contenido material se refiere, fue esbozado por la Sentencia 214.

Para esta Sentencia y para los magistrados que la suscriben, el aspecto más importante es prohibir, limitar y señalar obligaciones y cargas para organizaciones políticas y para todos los ciudadanos cuando lleven a cabo reuniones públicas o manifestaciones, pues deben agotar el procedimiento administrativo de autorización ante la primera autoridad civil de la jurisdicción correspondiente y, de esta manera, ejercer su derecho constitucional a la manifestación pacífica cuando en el derecho constitucional comparado no se presenta así.

Con lo anterior se quiere expresar que, aunque se acepta la existencia de límites al derecho a la protesta pacífica, estos deben comprender la existencia de un estado de necesidad de aquellos que lo ejercen; por ello, se impone un balance en su significado de derechos colectivos versus individuales en el momento de dirimir el conflicto mediante su ponderación. Esto no ha ocurrido en Venezuela: no se ha ponderado ni se ha equilibrado; al contrario, se le otorgó al Estado una nueva posibilidad para restringir el derecho de los individuos. El estado de necesidad

23 Comisión Interamericana de Derechos Humanos, Informe de la Relatoría especial para la libertad de expresión (Washington: OEA, 2009), párr. 70. 
al que se refiere implica una inmediatez que no se toma en cuenta y que traerá como consecuencia que las prescripciones contenidas en la decisión, en la mayoría de los casos prácticos, no sean observadas por los ciudadanos, tanto así que el recurrente de la Sentencia $214^{24}$ formula diversas interrogantes y la respuesta de la Sala constitucional no se hizo esperar:

En lo concerniente a la tercera duda, referida al hecho de que ¿el órgano administrativo que actúe en el marco de la Ley de Partidos Políticos, Reuniones Públicas y Manifestaciones, específicamente con base en los artículos 43, 44, 46 y 50 de esa ley, puede denegar, modificar o aprobar esa autorización mediante acto administrativo expreso?

De acuerdo con las previsiones de la Ley de Partidos Políticos, Reuniones Públicas y Manifestaciones, la primera autoridad civil de la jurisdicción donde se desee realizar la concentración, manifestación o reunión pública no se encuentra limitada a los términos en que se efectúe la solicitud, pudiendo no solo negar la autorización, sino también modificarla en caso de acordarla o autorizarla en cuanto a la indicación del lugar y el itinerario escogido (el día y hora). Dicho pronunciamiento, deberá ser emitido mediante acto administrativo expreso, en el cual se haga alusión a las razones o fundamentos de su decisión, aspectos estos que deberán ser tomados en consideración por el o los solicitantes al momento de recurrir de la decisión in comento. ${ }^{25}$

Independientemente de las razones que se esgriman para ello, el sustento axiológico de la naturaleza jurídica de los derechos humanos apunta a la dignidad del ser humano, a razones de orden moral y a justificaciones que se originan en la naturaleza del ser humano. Estos fundamentos han sido expresados en muchos momentos de la historia en diferentes declaraciones, documentos de independencia, carta de derechos y sentencias, entre otros. Aun cuando la Sentencia 214 interpreta el contenido del derecho humano a la manifestación pacífica, no menciona ni una sola vez la palabra dignidad; solo toca aspectos procedimentales.

Otra de las bases de la naturaleza jurídica de los derechos humanos está en la limitación del poder del Estado. En términos democráticos, podría afirmarse que su esencia parte del hecho de limitar el poder de quien lo detenta y sobran los datos

24 República Bolivariana de Venezuela, Tribunal Supremo de Justicia, Expediente No 140277
25 República Bolivariana de Venezuela, Tribunal Supremo de Justicia, Expediente $N^{o} 140277$ 
históricos para ello. La abolición de la monarquía absolutista y la modificación del concepto de soberanía que antes residía en el monarca para que luego residiera en el pueblo explican parte de esa evolución. En el derecho constitucional moderno esa tendencia se mantiene y es explicada mediante requisitos de existencia de la democracia, como la vigencia del principio de separación de poderes, la autonomía e independencia del poder Judicial y, por supuesto, la vigencia robustecida de un sistema de protección de derechos humanos cuya comprensión ha sido ampliada a aquellos que protegen a los individuos colectivamente, denominados derechos sociales.

La Sentencia 214 no pondera en sus argumentaciones la razón por la cual debe ser solicitado un permiso previo para llevar a cabo una manifestación pacífica cuando basta una mera notificación, pero tampoco explica el razonamiento necesario para que una manifestación pacífica en curso que no haya cumplido con los requisitos de la notificación deba ser considerada ilegal o ilícita; solo se limita a establecerlo y deja de lado los valores, los principios y las causas de la protesta.

Cuando define autorización necesaria para llevar a cabo una manifestación pacífica y considerarla ilegal o ilícita sin tal autorización, la sentencia 214 asume la vía contraria que transitan los regímenes democráticos de la región y del mundo, pues otorga más poder al Estado y disminuye los derechos de los ciudadanos venezolanos.

Para concluir, la Sentencia 214 solo puede ser entendida como la expresión de un Estado que se dirige a solidificar su autoridad en razones que no se acercan a la esencia del ser humano, sino a una estructura que a toda costa debe mantener un orden establecido y escinde al ser humano como centro, aunque es el elemento más importante de la sociedad.

\section{Perú}

El 7 de diciembre de 2005, el Tribunal Constitucional produjo una decisión sobre lo que la Constitución denomina derecho de reunión, el cual quedó delimitado por la decisión de su Corte Constitucional de la siguiente manera:

Contenido constitucionalmente protegido del derecho fundamental de reunión: El contenido constitucionalmente protegido del derecho viene configurado por la conjunción de una serie de elementos: a) Subjetivo: Se trata de un derecho individualmente titularizado, pero sólo susceptible de ejercitarse de manera 
colectiva. Lo ejercita una agrupación de personas con fines o propósitos, en esencia, comunes. La identidad básica de la intención de quienes se congregan, es decir, el factor volitivo común de los agrupados, es el que permite distinguir la reunión constitucionalmente protegida por el artículo $2^{\circ} 12$ de la Constitución, de aquellas meras aglomeraciones casuales de individuos a quienes no asiste tal identidad. Por ello, buenos ejemplos del ejercicio del derecho de reunión son el encuentro de los miembros sindicalizados para protestar por un hacer o no hacer de su empleador o empleadores, las marchas de los colectivos a quienes une el sentimiento de repudio frente a una medida adoptada por un poder público, las procesiones organizadas por los miembros de un determinado credo, los mítines coordinados por las agrupaciones políticas, etc. b) Temporal: Una de las características del derecho de reunión es la manifestación temporal o efímera de su ejercicio, incluso en los supuestos en los que tal manifestación sea periódica. Tal característica es uno de los principales factores que permite distinguirlo del derecho de asociación, reconocido en el artículo $2^{\circ} 13$ de la Constitución, al que inspira un ánimo de permanencia o, cuando menos, una determinada continuidad en el tiempo. c) Finalista: Es requisito fundamental para el válido ejercicio del derecho de reunión que su finalidad sea lícita. Dicha licitud no sólo debe ser predicable del propósito último de la reunión, sino de los medios cómo éste pretende ser alcanzado. Y es que cuando el artículo $2^{\circ} 12$ de la Constitución alude a que el modus de la reunión se materializa "pacíficamente sin armas", hace referencia a un requisito que atañe al contenido esencial del derecho, de manera tal que, desde el mismo instante en el que se manifiesta algún elemento objetivo que permita apreciar la intencionalidad o concreta actividad violenta durante la congregación, el o los individuos involucrados en el evento, dejan de encontrarse inmersos en el ámbito protegido del derecho, pudiendo ser reprimidos de forma inmediata, mediante medidas razonables y proporcionales, por la autoridad pública. d) Real o espacial: El derecho de reunión se ejerce en un lugar de celebración concreto. Así, el artículo $2^{\circ} 12$ de la Constitución establece que estos lugares pueden ser locales privados, locales abiertos al público, así como plazas o vías públicas. La selección del lugar en el que se lleve a cabo la congregación es vital para el libre ejercicio del derecho, puesto que muchas veces éste sólo puede alcanzar su propósito en atención a la proximidad física de los reunidos con aquellas personas o entidades destinatarios de las ideas, reclamos, pedidos, loas, etc. En otras ocasiones, el lugar escogido es representativo de la expresión o manifestación misma a la que la reunión sirve de instrumento. Resulta claro, sin embargo, que la elección del lugar no siempre puede quedar a discreción de la voluntad 
del celebrante, pues, en ocasiones, es el lugar escogido el que determina, ante el objetivo riesgo de afectación de determinados bienes constitucionalmente protegidos, la aparición de una causa objetiva y suficiente para restringir o prohibir la reunión. e) Eficacia inmediata: El hecho de que, a diferencia de las reuniones en locales privados o abiertos al público, el artículo $2^{\circ} 12$ de la Constitución exija un anuncio previo a la autoridad para realizar reuniones en plazas y vías públicas, puede llevar a la errónea impresión de que para el ejercicio de este último tipo de reuniones es imprescindible la autorización previa de algún representante gubernativo, siendo, en consecuencia, un derecho mediatizado en su manifestación a la anticipada aquiescencia expresa de la autoridad pública. Pues nada escapa de manera más evidente a la constitucional configuración del derecho sub examine. En efecto, el derecho de reunión es de eficacia inmediata y directa, de manera tal que no requiere de ningún tipo de autorización previa para su ejercicio. Lo que ocurre es que, en el caso específico de las reuniones convocadas en plazas o vías públicas, el constituyente ha establecido un instrumento expreso de armonización entre su ejercicio y las eventuales restricciones a otros derechos que éste represente, de manera tal que ordena que la autoridad tome noticia del evento con antelación suficiente a efectos de que tome las providencias necesarias para que el derecho al libre tránsito (artículo $2^{\circ} 11$ de la Constitución) no se vea limitado más allá de lo estrictamente necesario, habilitando vías alternas de circulación, además de adoptar las medidas necesarias para proteger a los manifestantes y asumir una conducta vigilante y, de ser el caso, proporcionalmente represiva, frente a las eventuales afectaciones a la integridad personal de terceros o de los bienes públicos o privados. Así las cosas, no cabe confundir la exigencia de aviso previo, con un supuesto sometimiento del derecho de reunión a la necesidad de una autorización previa de la autoridad administrativa, la cual, de ser exigida, resultará manifiestamente inconstitucional [9]. ${ }^{26}$

Estos planteamientos guardan una relación de semejanza con las sentencias de la Corte Constitucional colombiana, pero presenta notables diferencias con lo expuesto por la sentencia venezolana, ya que hace hincapié en que la notificación para ejercer el derecho a la protesta no es un obstáculo o prerrequisito. Tampoco hace referencia al estado de necesidad en el que pueda encontrarse el sujeto protestante y aquí sí hay una coincidencia con las sentencias analizadas.

26 República del Perú, Tribunal Constitucional, Exp. No 4677-2004-PA/TC (25/12/05). 
En el caso peruano, el derecho a la protesta presenta estos elementos:

- Carácter subjetivo. Aun cuando cada ciudadano lo posee en abstracto, es ejercido por un grupo.

- Carácter temporal. El tribunal peruano no toca aspectos de protestas que puedan prolongarse en el tiempo, pero sí hace alusión a una eventual periodicidad en la cual pudiera presentarse la situación fáctica.

- Finalidad lícita. Semejante a como está expuesto en el resto de los países analizados.

- Necesidad de un aspecto espacial específico en donde se desenvuelve la protesta, lo que deja por fuera ciertas protestas con particularidades diferentes.

- Eficacia inmediata. Está vinculada a la notificación de la protesta, lo que no la convierte en un requisito sine qua non para llevarla a cabo.

Esta sentencia del Tribunal Constitucional peruano ${ }^{27}$ plantea un tema que está en abierta oposición a lo expuesto en la sentencia de la Sala Constitucional venezolana con respecto al tema de la autorización previa y lo hace de la siguiente manera:

10.3 Las vías públicas como sede constitucionalmente reconocida para el ejercicio del derecho de reunión y la inconstitucionalidad del requisito de autorización previa.

29. Al expedir el inciso f) del artículo $132^{\circ}$ de la Ordenanza Municipal $\mathrm{N}^{\circ}$ 062-MML no se ha tenido en cuenta que la declaración como patrimonio cultural del Centro Histórico no ha relevado a sus calles y avenidas de la condición de vías públicas, expresamente reconocidas por el constituyente como lugares habilitados para el válido ejercicio del derecho de reunión.

30. Sobre el particular, no escapa a la consideración de este Colegiado que las vías públicas, son también, por antonomasia, áreas destinadas al ejercido de otro derecho fundamental: el de libre tránsito (artículo $2^{\circ} 11$ de la Constitución). Empero, la inevitable restricción a éste que una congregación llevada a cabo

27 República del Perú, Tribunal Constitucional, Exp. No 4677-2004-PA/TC (25/12/05). 
en una vía pública generará, en ningún caso, por sí sola, podrá considerarse causa suficiente para prohibir el ejercicio del derecho de reunión. Y es que, tal como tiene expuesto el Tribunal Constitucional español, en criterio que este Colegiado comparte, en una sociedad democrática, el espacio urbano no es sólo un ámbito de circulación, sino también un espacio de participación. [22]

31. Adicionalmente, no es posible soslayar que incluso al supuesto exceptuado de la prohibición absoluta de reuniones en el Centro Histórico (los eventos tradicionales), se le ha sometido al requisito de autorización previa, a pesar de que, tal como se ha sostenido en el Fundamento 15 e), supra, el derecho de reunión es de eficacia inmediata y, por consiguiente, no está supeditado a la autorización antelada de ninguna autoridad, sin perjuicio de la posibilidad de prohibir su ejercicio por razones constitucionalmente justificadas.

32. Por todos estos motivos, el Tribunal Constitucional considera inconstitucional el inciso f) del artículo $132^{\circ}$ de la Ordenanza Municipal N ${ }^{\circ}$ 062-MML, motivo por el cual, en ejercicio del control difuso de constitucionalidad de las normas, previsto en el artículo $138^{\circ}$ de la Constitución, lo declara inaplicable.

Como corolario del análisis, las mismas conductas analizadas en dos sentencias de tribunales diferentes arrojan resultados opuestos: mientras en Perú sería una conducta lícita protestar sin haber notificado, en Venezuela no.

Por último, la sentencia peruana presenta una referencia a la tolerancia como valor, extraída de una obra de Hans Kelsen, y se relaciona con la introducción de este trabajo, puesto que trata el punto de la necesidad de que la protesta como derecho ejercido sea llevada a cabo y escuchada:

La tolerancia ha sido reconocida por este Tribunal como "valor superior y principio rector de un sistema democrático" (STC 0042-2004-AI, Fundamento 3), en la medida que "el poder ejercido por la mayoría debe distinguirse de todo otro en que no sólo presupone lógicamente una oposición, sino que la reconoce como legítima desde el punto de vista político, e incluso la protege, creando instituciones que garantizan un mínimo de posibilidades de existencia y acción a distintos grupos religiosos, nacionales o económicos, aun cuando solo estén constituidos por una minoría de personas; o, en realidad, precisamente por constituir grupos minoritarios. La democracia necesita de esta continuada tensión entre mayoría y minoría, entre gobierno y oposición, de la que dimana 
el procedimiento dialéctico al que recurre esta forma estatal en la elaboración de la voluntad política. Se ha dicho, acertadamente, que la democracia es discusión. Por eso el resultado del proceso formativo de la voluntad política es siempre la transacción, el compromiso. La democracia prefiere este procedimiento a la imposición violenta de su voluntad al adversario, ya que de ese modo se garantiza la paz interna. ${ }^{28}$

Entonces, como lo entiende el Tribunal Constitucional, la forma como se garantiza que la protesta tenga un punto de llegada y el Estado esté obligado a canalizar el planteamiento esgrimido mediante el ejercicio de este derecho es la transacción.

\section{Análisis de la criminalización del derecho a la protesta a la luz de las decisiones de la CIDH}

En términos de organismos internacionales como cortes internacionales y otros órganos de protección de los derechos humanos, tenemos cuatro instrumentos básicos que comprenden y reconocen los derechos relativos a la protesta y reuniones pacíficas y que se encuentra en íntima relación con la criminalización de la protesta.

La Declaración universal de los derechos humanos, en el Artículo 20, establece el derecho a la libertad de asociación y reunión pacíficas. El Pacto internacional de derechos civiles y políticos, en su Artículo 21, prescribe el derecho de reunión pacífica y en el Artículo 22 se encuentra el derecho de asociación.

Estos instrumentos internacionales no plasman de manera explícita el derecho de manifestación, porque el derecho de reunión lo contiene en sí mismo. No obstante, la Declaración americana de derechos y deberes del hombre hace alusión expresa a la manifestación pública en su Artículo 211 y asegura el derecho de asociación en el Artículo 22. La Convención americana sobre derechos humanos o Pacto de San José define el derecho de reunión en el Artículo 15 y la libertad de asociación, en el 16.

Entre las características similares de los instrumentos internacionales aludidos se resalta que el ejercicio del derecho a la reunión y manifestación debe ser pacífico, sin alterar los derechos de terceros ni el orden público. En lo relativo al derecho de asociación, sobresale el hecho de que la asociación debe tener fines lícitos y además

28 República del Perú, Tribunal Constitucional, Exp. No 4677-2004-PA/TC (25/12/05). Confederación General de Trabajadores del Perú (CGTP) vs. Municipalidad Metropolitana de Lima de 7 de diciembre de 2005. 
puede surgir para la defensa o protección de diversos intereses manifestados por las personas que se asocian.

Sin embargo, este estudio busca exponer otra forma con la que los Estados fijan límites y regulan los derechos de protesta y asociación. Se trata de la criminalización del derecho a la protesta, cuya regulación tiene una perspectiva diferente a las sentencias analizadas.

\section{Sentencia de la CIDH frente a Chile sobre la criminalización del derecho a la protesta}

Este asunto se sometió a la jurisdicción de la Corte Interamericana de Derechos Humanos el 7 de agosto de 2011 y se denominó Segundo Aniceto Norín Catrimán, Juan Patricio Marileo Saravia, Víctor Ancalaf Llaupe y otros vs. República de Chile y su fundamento estuvo en el procesamiento de los quejosos por la condena por delitos terroristas, en aplicación de una normativa penal contraria al principio de legalidad con una serie de irregularidades que afectó el debido proceso y tomó en consideración su origen étnico de manera injustificada y discriminatoria.

Parte de la situación que rodea el caso analizado se describe en la sentencia de la Corte Interamericana de los Derechos Humanos:

A inicios de la década de los 2000, época en que ocurrieron los hechos por los cuales fueron condenadas penalmente las presuntas víctimas de este caso, existía en el sur de Chile (Regiones VIII, IX y X), fundamentalmente en la IX Región (de la Araucanía), una situación social de numerosos reclamos, manifestaciones y protestas sociales por parte de miembros del Pueblo indígena Mapuche, líderes y organizaciones del mismo, con el fin de que fueran atendidas y solucionadas sus reivindicaciones, fundamentalmente referidas a la recuperación de sus territorios ancestrales y al respeto del uso y goce de dichas tierras y sus recursos naturales. La protesta social en la zona se vio incrementada por el impacto de que, desde finales del siglo XX, se permitiera una mayor explotación por empresas forestales y la construcción de proyectos de desarrollo en parte de las tierras que las comunidades mapuche consideran que constituyen sus territorios tradicionales. Ello trajo como consecuencia que "las cada vez más reducidas tierras comunales se [encuentren] aisladas dentro de propiedades de particulares, [afectando el] acceso a los bosques que son el tradicional medio de subsistencia de los mapuche". Además, la construcción de "grandes proyectos 
de desarrollo" en la primera década del siglo XXI, como centrales hidroeléctricas y carreteras, generó una serie de "conflictos sociales en torno a los efectos sobre los derechos humanos de los indígenas". La construcción de la central hidroeléctrica Ralco en la Provincia de Bío Bío, VIII Región, tuvo particular impacto y oposición de las comunidades indígenas por las miles de hectáreas de tierra que serían inundadas y comunidades trasladadas. En el contexto de esa protesta social se incrementó el nivel de conflictividad en dichas regiones. Aparte de las movilizaciones sociales y de otras medidas de presión como la ocupación de las tierras demandadas, se presentaron algunas acciones de hecho y violentas calificadas como "graves", tales como la ocupación de tierras no ligadas a procedimientos de reclamación en curso, incendio de plantaciones forestales, cultivos, instalaciones y casas patronales, destrucción de equipos, maquinaria y cercados, cierre de vías de comunicación y enfrentamientos con la fuerza pública 81. En ese contexto ocurrieron los hechos por los cuales fueron procesadas penalmente las ocho presuntas víctimas del presente caso: a) incendio ocurrido el 12 de diciembre de 2001 en el predio forestal Nancahue y en la casa del administrador del predio, por el cual resultaron absueltos los Lonkos Segundo Aniceto Norín Catrimán y Pascual Pichún Paillalao (infra párrs. 106, 112 y 116); b) hechos de "amenazas" de quemar el predio San Gregorio "ocurrid[o]s durante el año 2001" por los cuales fue condenado el Lonko Segundo Aniceto Norín Catrimán (infra párrs. 106, 116 y 118); c) incendio ocurrido el 16 de diciembre de 2001 en el predio forestal San Gregorio, por el cual resultaron absueltos los Lonkos Segundo Aniceto Norín Catrimán y Pascual Pichún Paillalao (infra párrs. 106, 112 y 116); d) hechos de "amenazas" de incendio del predio Nancahue "ocurrid[o]s durante el año 2001" por los cuales fue condenado el Lonko Pascual Pichún Paillalao (infra párrs. 106, 112 y 116); e) incendio ocurrido el 19 de diciembre de 2001 en los fundos Poluco y Pidenco, propiedad de la empresa forestal Mininco S.A., por el cual fueron condenados Juan Patricio Marileo Saravia, Florencio Jaime Marileo Saravia, José Benicio Huenchunao Mariñán, Juan Ciriaco Millacheo Licán y Patricia Roxana Troncoso Robles (infra párrs. 120, 126 y 128); f) quema de tres camiones y una retroexcavadora propiedad de la empresa Fe Grande (que trabajaba en la construcción de la represa Ralco) los días 29 de septiembre de 2001 y 3 de marzo de 2002 en el sector Alto Bío Bío, por los cuales resultó absuelto el Werkén Víctor Ancalaf Llaupe (infra párrs. 133 y 147), y g) quema de un camión propiedad de la empresa constructora Brotec S.A. (que trabajaba en la construcción de la represa Ralco) el 17 de marzo de 
2002 en el sector Alto Bío Bío, por el cual fue condenado el Werkén Víctor Ancalaf Llaupe (infra párrs. 133, 147, 150 y 151). ${ }^{29}$

Para mayor comprensión del lector, es necesario un planteamiento general del caso en la cita que antecede, en la cual se nota que, en virtud del ejercicio del derecho a la protesta, se llevaron a cabo acciones que están debidamente detalladas. Estas acciones de los protestantes fueron asumidas por los organismos competentes del Estado chileno de manera que resultaran sometidos a procesos criminales que implicaban la privación de la libertad. La sentencia de la Corte Interamericana de Derechos Humanos explica de la siguiente manera:

El 22 de agosto de 2004 el Tribunal de Juicio Oral en lo Penal de Angol emitió sentencia 136, en la cual condenó a los imputados como "autores del delito de incendio terrorista", por el "hecho cometido durante el día 19 de diciembre de 2001, en el fundo Poluco Pidenco de la comuna de Ercilla"137. Les impuso la pena de diez años y un día de presidio mayor en su grado medio y las penas accesorias de "inhabilitación absoluta perpetua para cargos y oficios públicos y derechos políticos e inhabilitación absoluta para profesiones titulares mientras dure la condena". También acogió la demanda civil y los condenó solidariamente a pagar a la empresa Forestal Minico S.A. la suma de $\$ 424.964 .798$ pesos chilenos por concepto de daños materiales. ${ }^{30}$

En el momento que la sentencia determina la culpabilidad de los imputados por el delito de incendio terrorista, el Estado chileno muestra una forma específica para tratar conductas y consecuencias que surgen del ejercicio del derecho a la protesta: las asume como tipo penal y prescinde de consideraciones relacionadas con el marco de actuación; esto ubica al Estado chileno en la línea de criminalizar tales conductas, pues no pondera tal característica con la acción que se castiga.

De esta manera, el Estado va definiendo las formas de intervenir en el ámbito social, al utilizar diferentes elementos; la represión es uno de ellos, cuando establece, mediante sentencias, que la protesta es cercana a la ilegalidad y la encuadra en tipos penales que la interpelan como delito.

\footnotetext{
Corte Interamericana de Derechos Humanos, Caso Norín Catrimán y otros (dirigentes, miembros y activista del pueblo indígena Mapuche) vs. Chile. Sentencia de fondo, reparaciones y costas, 29 de mayo de 2014.

30 Corte Interamericana de Derechos Humanos, Caso Norín Catrimán y otros.
} 
En la misma línea de pensamiento expresada en el párrafo anterior, la opinión expresada por la Personería Medellín presenta similitudes destacables:

Ante la situación planteada, la protesta social muestra una constante mundial de reducción de marcos legales y represión, por tal razón no es aislado ni resulta de la nada, que en Colombia sea cada vez más "regulada". De igual forma, es necesario entender la protesta en todas sus dimensiones como: derecho, mecanismo de protección y conquista de derechos, mecanismo de participación política y forma alternativa de comunicación. Tales situaciones, nos motivan a construir una reflexión jurídica, filosófica y sociológica alrededor de lo que es la protesta, y las tensiones que se presentan. ${ }^{31}$

De acuerdo con Ana Musolino, respecto a la criminalización de la protesta en Chile:

Partimos de considerar, como venimos marcando a lo largo del trabajo, que la criminalización y judicialización de la protesta es una herramienta más en la configuración del capitalismo en el momento histórico actual. Herramienta definida política y no jurídicamente. Estos procesos de criminalización no son nuevos ni dependen del gobierno de turno, sino que se constituyen, históricamente, en una política de Estado. Sin embargo, en los últimos años ambos procesos se han complejizado, por el mismo recrudecimiento de la crisis económica y el aumento de la protesta social; avanzando o renaciendo la búsqueda de «legalización» de las formas represivas y agravándose las imputaciones que recaen sobre los manifestantes y protagonistas de las protestas. "Si al inicio de las protestas masivas las imputaciones resultaban ser por delitos menores, de los llamados correccionales (atentado y resistencia a la autoridad, obstrucción del tránsito o similares), con el transcurso de los años éstas fueron alcanzando mayor gravedad. En la actualidad, la mayoría de los casos se les imputan a los detenidos delitos criminales no excarcelables, como coacción agravada, privación ilegítima de la libertad, sedición y similares, apuntando a transformar la detención en prisión preventiva. ${ }^{32}$

Para resumir, podemos afirmar que en los casos analizados existe una tendencia a regular el derecho a la protesta desde el enfoque de limitar el disenso a la decisión que los órganos gubernativos han tomado; cuando esta limitación es superada, se

31 Personería de Medellín, "Protesta social: entre derecho y delito", 134.

32 Musolino, "Criminalización y judicialización de la protesta social en Argentina", 9. 
apunta a criminalizar los actos configurativos del derecho a la protesta. La opinión de Prieto Sanchíz, cuando analiza la libertad de conciencia, es útil al argumento que se desarrolla.

Por su parte, la CIDH ha expresado diversas opiniones y la siguiente resume el criterio orientador:

Al igual que sucede con cualquier enunciado o disposición normativa, los preceptos que reconocen derechos fundamentales contienen distintas normas o modalidades de ejercicio. En ocasiones, cuando la formulación del derecho ofrece referentes empíricos más o menos precisos, como sucede por ejemplo con el derecho de manifestación en la vía pública (art. $21 \mathrm{CE}$ ), dichas modalidades son limitadas y hasta cierto punto previsibles a la vista del propio enunciado constitucional: procesiones, cortejos, concentraciones, etc. Sin embargo, en otros casos parece que cualquier intento de catalogar las posibles modalidades de ejercicio de un derecho está destinado al fracaso, y así sucede con la libertad de conciencia en la interpretación que presenta nuestra sentencia: si es cierto que dicha libertad comprende el derecho a obrar de manera conforme a las propias convicciones, entonces prácticamente toda conducta (o casi) queda amparada por el tipo constitucional. ${ }^{33}$

\section{Conclusiones}

El desarrollo de este estudio cumple con un postulado importantísimo de toda investigación: convertirse en un punto de partida para agregar elementos que permitan establecer características del derecho a la protesta y, a su vez, sirva como base para profundizar en el análisis, tanto desde la perspectiva del derecho propiamente dicho como desde el punto de vista práctico.

Como hicimos referencia en varias oportunidades, el derecho a la protesta debe tomar en cuenta el estado de necesidad de quien lo ejerce y podría afirmarse que posee una analogía con el derecho a la defensa, que también está consagrado como derecho humano en todo ordenamiento jurídico; se defiende aquel a quien en teoría le ha sido violado un derecho y protesta todo aquel que es alcanzado por una decisión del órgano que ostenta el poder y con la cual se difiere.

33 Prieto Sanchís, "Libertad y objeción de conciencia", 261. 
La revisión jurisprudencial que se llevó a cabo sobre decisiones de los máximos tribunales de algunos países permite establecer diferencias ostensibles entre estos Estados. En unos, el ejercicio de la autoridad es más amplio y tolera de mejor manera las formas de disenso; en otros, la tolerancia a la protesta es mínima y muy rápidamente se convierte en un acto ilegal o antijurídico. Otros Estados optan por caminos diferentes, por ejemplo, convierten todo acto que se erija como protesta en uno considerado criminal: la protesta no es asumida como tal, sino como un delito (criminalización de la protesta).

También observamos el visible interés de los organismos internacionales por encontrar cauces al ejercicio de este derecho tan importante. Se nota que los órganos judiciales de cada país fijan sus límites para que el orden genere el establecimiento de una estructura aceptada socialmente. Por ejemplo, los cortes de vía, como ejercicio del derecho a la protesta, en unos países tienen ciertas limitaciones y en otros es considerado un delito o incumplimiento de la ley.

El tema del derecho a la protesta siempre se mantendrá en las mentes de sociólogos, juristas y politólogos, pues posee muchas aristas que tocan estas ciencias sociales; cada expresión que vemos a diario en lo atinente a la protesta estará referida a las líneas que se han investigado o constituirán un aspecto novedoso o inédito para agregar a sus planteamientos.

Algunas de las características más sobresalientes del derecho a la protesta se evidencian en tres aspectos: el estado de necesidad, la razón por la cual se protesta y la forma como se hace. No es igual protestar por la violación de un derecho político que por hambre y, desde el punto de vista de la forma de la protesta, tampoco es lo mismo cerrar vías cuando existen otras alternas que impedirlo totalmente; es distinto protestar en un momento determinado ante el apremio de la violación de los derechos y hacerlo cuando ya se produjo la situación y el tiempo ha pasado. Todos estos elementos deben ser tomados en cuenta a la hora del establecimiento fáctico de las situaciones que objetivamente se presentan y las consecuencias que se derivan de ellas.

Otro ángulo que debe considerarse es que una sociedad en donde el derecho a la protesta se ejerce sin exceso de limitaciones, es una sociedad libre y permitirá al individuo encausar su conducta y adaptarla a sus intereses de la mejor manera. 
Los excesos de regulación traducen una voluntad estatal dirigida a limitar la libertad del individuo y a imponer parámetros al disenso en las decisiones mediante la vía de la voluntad general. En la medida en que el disenso se canaliza de manera más amplia, la sociedad encontrará paz.

No podemos obviar la vieja dualidad del derecho positivo frente al derecho natural, lo que nos permite afirmar con Maurice Duverger que "la dualidad esencial del derecho natural y el derecho positivo, y la subordinación del segundo al primero, sienta un principio fundamental del debilitamiento del poder". ${ }^{34}$

En el fondo, el derecho a la protesta y su ejercicio son útiles para establecer el grado de mayor o menor libertad de una sociedad. Toda sociedad a la que no se le permita el disenso canalizará su inconformidad en la protesta. Basta con imaginar cualquiera de las decisiones de los más altos tribunales que se analizaron en este trabajo aplicada a las protestas organizadas por Ghandi o Luther King y podremos concluir que, aun cuando establecer parámetros para el ejercicio práctico de este derecho es un esfuerzo loable, su importancia deriva de aquellas situaciones que generan el disenso y hallan relación de vinculación con los atributos más importantes del ser humano: su dignidad y su libertad.

Es importante estudiar con más detenimiento la relación de la dignidad y la libertad del ser humano con el derecho a la protesta, en tanto son sostén de conductas basadas en el desarrollo de la ética y la moral, como elementos que atraviesan la existencia del ser humano. Sería inconcebible defender cualquier protesta que defienda el mal desde el punto de vista de su esencia, tema que puede ser eje de un análisis pertinente.

El esfuerzo de esta investigación estuvo dirigido en parte a examinar las decisiones de los más altos tribunales de diversos países, magistraturas que han fijado un marco en el cual el derecho a la protesta puede desenvolverse. Este derecho, de importancia superlativa, trae como consecuencia la democratización de la sociedad.

34 Maurice Duverger, Instituciones politicas y derecho constitucional (Barcelona: Ariel, 1970), 42. 


\section{Referencias}

Bobbio, Norberto, Nicola Metteucci y Gianfranco Pasquino. Diccionario de política. Ciudad de México: Siglo XXI Editores 2007.

Colectivo Ioé. "La participación política de los españoles: democracia de baja intensidad". Papeles, núm. 99 (2007): 149-163. https://www.colectivoioe.org/uploads/1f938f58 5c6417albf7aal6aef90acdd262cf860.pdf

Colombia, Corte Constitucional. Sentencia C-742 de 26 de septiembre de 2012. M. P. María Victoria Calle Correa.

Comisión Interamericana de Derechos Humanos. Informe de la Relatoría especial para la libertad de expresión. Washington: OEA, 2009.

Corte Interamericana de Derechos Humanos. Caso Norín Catrimán y otros (dirigentes, miembros y activista del pueblo indígena Mapuche) Vs. Chile. Sentencia de fondo, reparaciones y costas, 29 de mayo de 2014.

Duverger, Maurice. Instituciones politicas y derecho constitucional. Barcelona: Ariel, 1970.

Gargarella, Roberto. "El derecho a la protesta social". Derecho y Humanidades, núm. 12 (2006): 141-151.

Gargarella, Roberto. "La última carta. El derecho de resistencia en situaciones de alienación legal". SELA (Seminario en América Latina de teoría constitucional y política) Papers, núm. 24 (2003). http://digitalcommons.law.yale.edu/yls_sela/24/

Gargarella, Roberto. Carta abierta sobre la intolerancia. Apuntes sobre derecho y protesta Ciudad de México: Siglo XXI Editores, 2006.

Grupo interdisciplinario de Bioética. "Objeción de conciencia en el ámbito de los profesionales de la salud”. Bioética y Debate 18, núm. 66 (2012). http://www.bioetica-debat.org/ contenidos/PDF/BD66ESP.pdf (acceso octubre 10, 2016).

Ilivitzky, Matías Esteban. "La desobediencia civil: aportes desde Bobbio, Habermas y Arendt". CONfines 7, núm. 13 (2011). http://confines.mty.itesm.mx/articulos13/llivitzkyM. pdf (acceso octubre 10, 2016).

Musolino, Ana. "Criminalización y judicialización de la protesta social en Argentina: cuando la lucha y la resistencia popular se vuelven delito". Tesis de pregrado para optar al título de licenciada en Trabajo social, Universidad Nacional de Cuyo, 2009.

Organización de Naciones Unidad [ONU]. Pacto internacional de derechos civiles y politicos. Nueva York, 16 de diciembre de 1966.

Personería de Medellín. "Protesta social: entre derecho y delito". Pensamiento Politiko 2, núm. 2 (2010): 113-212. http://dialnet.unirioja.es/descarga/articulo/3860600.pdf (acceso octubre 10, 2016).

Prieto Sanchís, Luis. "Libertad y objeción de conciencia". Persona y Derecho 54 (2006): 259-273. http://hdl.handle.net/10171/14621 (acceso octubre 10, 2016). 
República Bolivariana de Venezuela, Tribunal Supremo de Justicia. Expediente $N^{o} 140277$ de marzo de 2014. M. P. Arcadio Delgado Rosales.

Suárez, Francisco. Guerra, intervención y paz internacional. Traducido por Luciano Pereña y Vicente. Madrid: Espasa-Calpe, 1956.

Thoreau, Henry D. Desobediencia civil y otros escritos. Madrid: Tecnos, 2008.

República del Perú, Tribunal Constitucional. Exp. N 4677-2004-PA/TC (25/12/05). Confederación General de Trabajadores del Perú (CGTP) vs. Municipalidad Metropolitana de Lima de 7 de diciembre de 2005.

Vázquez, Carlos Simón. "La objeción de conciencia en la práctica médica" en Actas del I Congreso internacional multidisciplinar Mujer y realidad del aborto, editado por Manuel Lázaro Pulido, 193-202. Cáceres: Asociación Extremeña de Amigos del Foro Español de la Familia, 2008. 